\title{
A Hevenesi-, Kaprinai-, Pray-kéziratgyüjtemény feldolgozásának kérdései
}

A tanulmány szerzőjének egy korábbi, Hevenesi-, Kaprinai-, Pray-kéziratgyüjteményről szóló dolgozatában ${ }^{1}$ (felhasználva Knapp Éva e tárgyban született írásait² rövid összefoglalás olvasható a gyüjtemény általános jellemzőiről, forrásértékéről, az ELTE Egyetemi Könyvtár tulajdonába kerülés mikéntjéről és a lehetséges vizsgálati területekről. A jelen írás elsősorban a kéziratos gyüjtemények összetételére, valamint a könyvtári feldolgozásuk során alkalmazott módszerre fókuszál.

Az egyes kötetek tartalmát és összetételét Hóman Bálint ismerteti ${ }^{3}$ részletesen, bár ennek megjelenése óta néhány kötet máshová került az Egyetemi Könyvtár gyüjteményében (erről részletesen Tóth András számol be a „Holt” kéziratgyüjtemények élete 4 címü munkájában). Tóth András írását ${ }^{5}$ követően a Pray-gyüjtemény 11 kötettel gyarapodott, amelyek a Coll. Pray 61-71. jelzet alá kerültek. Az Egyetemi Könyvtár 1996 decemberében visszaadta a Cod. lat. 113. jelzetủ kódexet ${ }^{6}$ a Pannonhalmi Főapátság Könyvtárának, mint eredeti őrzőhelynek (amely a Főapátság gyüjteményében a Pannonhalmi Evangelistarium címmel található), tőlük pedig ide került Pray fent említett 11 kötetnyi forrásgyüjtése. ${ }^{7}$

Mivel az oklevélmásolatok egy meghatározó részét adják a gyüjteménynek ${ }^{8}$, érdemesnek tünik megvizsgálni, hogy valójában mennyi az oklevelek és okle-

${ }^{1}$ Mátyás Melinda: Jezsuita tudósok digitalizált kéziratgyüjteményei az ELTE Egyetemi Könyvtárban és lehetséges kutatási témáik = Valóságos könyvtár - könyvtári valóság. Szerk. Kiszl Péter, Boda Gáborné Köntös Nelli. Budapest, ELTE BTK Könyvtár- és Információtudományi Intézet. 2017. megjelenés alatt

${ }^{2}$ Knapp Éva: A Kézirat- és Ritkaságtár tudományos ismertetője. = Az Egyetemi Könyvtár története és gyüjteményei. Szerk. Szögi László. Budapest, ELTE Eötvös Kiadó. 2008. 191-216. p. Knapp Éva: A Budapesti Egyetemi Könyvtár Kézirattárának Levélgyüjteménye. = Az Eötvös Loránd Tudományegyetem Egyetemi Könyvtárában és Egyetemi Levéltárában őrzött 1526 előtti oklevelek és iratok jegyzéke. Szerk. Sölch Miklós. Budapest, ELTE Egyetemi Könyvtár. 2005. 33-36. p.

${ }^{3}$ Hóman Bálint: Kishevesi Hevenesi Gábor. = Történetírás és forráskritika. 2. köt. Hóman Bálint. Budapest, Attraktor. 2003. 321-332. p.

${ }^{4}$ Tóth András: „Holt" kéziratgyüjtemények élete. = Magyar Könyvszemle, 1958. 42-50. p.

${ }^{5}$ Tóth András i.m.

${ }^{6}$ Tóth Péter: Catalogus codicum latinorum medii aevi Bibliotheca Universitatis Budapestinensis. Budapest, 2008. https://edit.elte.hu/xmlui/bitstream/handle/10831/32258/Toth\%20Peter Catalogus\%20codicum\%20latinorum\%20medii\%20aevi\%20Bibliotheca\%20Universitatis\% $\%$ Budapestinensis.pdf?sequence $=1$ \&isAllowed $=y \#$ page $=294$ (2016. október 25.)

${ }^{7}$ Bánhegyi B. Miksa: A Pannonhalmi Főapátsági Könyvtár. = Könyv és könyvtár, 19. évf. 1997. 19-33. p.

${ }^{8}$ Lsd. Borsa Iván: A magyar medievisztika forráskérdései. = Levéltári közlemények, 44-45. évf. 1973. 1-2. sz. 103-121. 
vélmásolatok aránya a jezsuita tudósok kéziratgyüjteményeiben. Ehhez Dedek Crescens Lajos katalógusát ${ }^{9}$ vettük alapul, és megjelöltük a kollekciók egyes köteteinél, hogy oklevélmásolatot tartalmaz-e a benne található kéziratok többsége vagy nem. Az kapott érték a vizsgálat módja miatt inkább megközelítő becslésnek nevezhető. Azt is figyelembe kell venni, hogy vannak hiányzó kötetek, amelyeket Dedek is említ a katalógusában: a Hevenesi-gyüjteményből két, a Prayból pedig négy kötet hiányzik. Összesítve azt az eredményt kaptuk, hogy a három gyüjteménynek körülbelül a fele oklevélmásolat; a kötetek számát tekintve pedig 145 kötet oklevélmásolat, 152 más típusú kézirat. Az egyes kollekciókat megfigyelve a Kaprinai B (negyedrét méretü iratok) tartalmazza a legtöbb oklevélmásolatot: 50 kötetet számlál, és 52, többségében más kéziratos anyagot tartalmazó egységet. A kettedrét méretű dokumentumokból álló Kaprinai A gyűjteményről elmondható, hogy föként az oklevélmásolatoktól különböző forrásokat tartalmaz: 39 kötetének nem oklevélmásolat a nagyobb része, és 15 kötet tartalmaz főként oklevélmásolatot. A Pray- és Hevenesi-gyüjteményekre vonatkozó számokat lásd a táblázatban (1. táblázat).

\begin{tabular}{|l|c|c|c|}
\hline \multicolumn{1}{|c|}{ A kéziratok jellege } & $\begin{array}{c}\text { Hevenesi (2 kötet } \\
\text { hiányzik) }\end{array}$ & $\begin{array}{c}\text { Kaprinai A és } \\
\text { B együtt }\end{array}$ & $\begin{array}{c}\text { Pray (4 kötet } \\
\text { hiányzik) }\end{array}$ \\
\hline oklevélmásolat a többség & 53 & 65 & 27 \\
\hline nem oklevélmásolat a többség & 36 & 52 & 29 \\
\hline
\end{tabular}

1. táblázat. Oklevélmásolat-arányok

Az oklevélmásolatok mellett a másik nagy forrásértékủ része a kollekcióknak az egyedi történeti kéziratok, ezek közül is kiemelhető néhány. Így Szamosközy István két műve: az Erdély története címü (Pentades) autográf kézirat, amely a Hevenesi-gyüjtemény 11. kötetében található (a Rerum Ungaricarum címü írásával együtt), és a Hebdomadis címủ írás VI-VIII. könyvének kézirata (Hevenesigyüjtemény 15. kötet). A kéziratok első kiadója az ELTE Egyetemi Könyvtár korábbi föigazgatója, Szilágyi Sándor volt, aki Szamosközy István történeti maradványai címmel jelentette meg a müveket. ${ }^{10}$ Magyar nyelven először Borzsák

${ }^{9}$ Catalogus manuscriptorum Bibliothecae Regiae Scientiarum Universitatis Budapestinensis. Tom. II. Pars 2. Catalogus litterarum originalium ac collectionis Hevenessianae et Prayanae. Budapest, 1894. http://hdl.handle.net/10831/32254 (2016. október 11.) és Catalogus manuscriptorum Bibliothecae Regiae Scientiarum Universitatis Budapestinensis. Tom. II. Pars 3. Catalogus collectionis Kaprinayanae. Budapest, 1907. http://hdl.handle.net/10831/32256 (2016. október 25.)

${ }^{10}$ Szamosközy István történeti maradványai 1566-1603. (Monumenta Hungariae Historica. II. Scriptores. XXI. és XXVIII.). Kiadta: Szilágyi Sándor. Budapest, 1876; XXIX. Budapest, 1877 és Pataki József: Szamosközy István magyar nyelvű feljegyzései. = Erdélyi Múzeum, 53. évf. 1991. 1-4. sz. 154-157. p. 
István fordításában jelent meg válogatás a Pentades-ből ${ }^{11}$ és a Hebdomadis-ból 1963-ban, ${ }^{12}$. Szamosközy István volt az első magyar kutató, aki csak a forrásgyüjtéssel és történetírással akart foglalkozni, és ehhez módszeres levéltári kutatásokat folytatott ${ }^{13}$. A második kiemelt szerző Bzenszky Rudolf, az erdélyi anyag kutatója ${ }^{14}$, aki a Syllogimaea Transylvanae Ecclesiae per historiophilum címü mü írója. Fontos még megemlíteni Paulus Rittert, akinek a Natales D.(ivo) Ladislavo R.(egi) Slavoniae Apostolo Restituti címü írását őrzi kéziratosan Hevenesi 75. kötete (Dedek-katalógus szerinti 5. tétel). E münek az az érdekessége, hogy nyomtatásban a szakirodalom szerint egy példány maradt fenn, amely a zágrábi Nemzeti és Egyetemi Könyvtárban található, és valószínűleg 1704-ben került kiadásra ${ }^{15}$. A Pray-gyüjtemény 9. kötetében (Dedek szerinti 22. tétel) olyan érdekességekre is bukkanhatunk, mint Janus Pannonius levelezése, amelynek összeállítója valószínüleg Brodarics István volt ${ }^{16}$.

A máig teljességgel fel nem tárt gyüjtemények szempontjából a kutatást nagy mértékben segítheti, hogy a jelenleg Hevenesi-, Kaprinai-, Pray gyüjteményt képező kéziratos anyag teljességgel elérhető digitális formában. A kollekciók két forrástípusának kiemelése után nézzük meg röviden a digitalizálási munkát, és az azt követő javítási munkálatokat! A digitalizálás 2010-2011-ben történt az Arcanum Kft. közremüködésével. A kéziratoknál különösen fontos, hogy a lap minden része látható legyen a digitális másolaton (az eredetileg digitalizált képeken például szöveghiány volt a lap szélén, szamárfüles oldalak maradtak), ezért az Egyetemi Könyvtár munkatársainak koordinálásával célszerűnek tünt a körülbelül tíz százaléknyi, nem teljesen olvasható oldal újbóli szkennelése. Az egyes másolatok metaadatolására 2013-2014 között került sor egy NKA-pályázatnak köszönhetően. Ennek során feldolgozásra került az egész szkennelt anyag a Dedek-katalógus tételekre való bontása szerint. A tételek kiegészültek egy-egy példányadattal is, ez biztosítja, hogy vissza lehet keresni azokat a Dedek-katalógusban elfoglalt hely szerint. Ehhez ismerni kell az egyes gyüjtemények rövidítését a katalógusban: a Hevenesié collhev, a Kaprinai A-jé: collkapra, a Kaprinai B-jé collkaprb, a Prayféle pedig collpray. A jelzet további részei, amelyek szükségesek a pontos hely szerinti visszakereséshez: a kötet és a tételszám leírása három számjegyre kiegészítve: például, ha a Dedek-katalógus szerinti Kaprinai B 4. kötetének 12. tételét

${ }^{11}$ Szamosközy István: Erdély története. I. kiad. Budapest, Magyar Helikon. 1963; II. kiad. Magyar Helikon. 1977.

${ }^{12}$ Pataki József i.m.

${ }^{13}$ Hóman Bálint: Kishevesi Hevenesi Gábor. = Történetírás és forráskritika. 2. kötet. Hóman Bálint. Budapest, Attraktor. 2003, 321-332 p.

${ }^{14}$ Hóman Bálint i.m.

${ }^{15}$ Szörényi László: Paulus Ritter Szent László életrajza. = Irodalomtörténeti Közlemények, 103. évf.1999. 3-4.sz. 416-448. p.

${ }^{16}$ Ritoókné Szalai Ágnes: Janus Pannonius leveleinek kézirata a Pray-gyüjteményben. $=\mathrm{Az}$ Egyetemi Könyvtár évkönyvei, 14-15. évf. 2011. 283-291. p. 
keressük, akkor a következőt kell beírni a Gyüjtemény/jelzet keresőmezőbe az opac.elte.hu oldalon: collkaprb004_012*. A csillag karakterre azért van szükség, hogy az utána levő verzió-számozásra is keressen, ezzel bármely számú karaktert helyettesítünk. Ha lemarad a csillag, akkor is kapunk találatot: a Böngészésbe léptet a rendszer, ahol ki lehet választani a 12. tételt.

A feldolgozás során az idő rövidsége miatt a Dedek-katalógusból való adatrögzítés egy tömeges adatbevitellel történt, ezért szükséges az ekkor felvett és azonosított adatok átnézése és javítása, kiegészítése. A munka kezdetén a következő problémákkal, kérdésekkel szembesültünk:

a) Nehezen olvasható kézírások

b) Megbízható-e a másolat?

c) Hamisított oklevelek másolatai

d) A teljes egység végigolvasása nélkül meg lehet-e állapítani biztonsággal a metaadatokat?

e) Mi a könyvtáros és mi már a kutató feladata?

Az a) esetben jobban szükséges támaszkodni Dedek leírására, és a kéziratolvasási tapasztalatok alapján lehetséges hozzátenni, ami még bizonyossággal kiolvasható. Például Kaprinai István nagyon sok oklevelet másolt maga, szerencsére az ő kézírása igen szép és olvasható. A b) felvetés jogosságát alátámasztja például Szentgyörgyi Rudolf tanulmánya ${ }^{17}$, amelyben elvégzett egy gondolatkísérletet arról, hogy mi lett volna, ha A tihanyi apátság alapítólevele csak a korai kéziratos oklevélgyüjteményekben maradt volna fent. Kutatásából kiderült többek között, hogy a vizsgált szövegrészletek az egyik Kaprinai-másolatban (64. kötet: 36-43.) találhatók meg nem megbízható formában. Ez a szempont, valamint a c) és a d) felvetések óvatosságra intenek a feldolgozásban annak tekintetében, hogy mit tüntessünk fel a katalógusban azonosított adatként, és mit ne. A másolatokban található összes személynév és helységnév azonosítása például valószínüleg nem járható út, egyrészt mivel ez túlmutatna a könyvtárosi feladatokon, másrészt a meglévő eszközeinkkel nem, vagy csak indokolatlanul nagy időráfordítás révén tudnánk megbízhatóan megállapítani.

E szempontok figyelembevételével az adatok gazdagításához a Diplomatikai Levéltár és Fényképgyüjtemény (DL-DF) mintájára a következő típusoknak a javítását, kiegészítését tüztük ki célul a középkori oklevélmásolatok esetében:

a) A kiadó/kibocsátó: ezt az adatot többnyire Dedek is azonosítja, és mivel általában ismert történelmi személyről vagy intézményről van szó, biztonsággal fel lehet venni a helyes alakját. Az elektronikus katalógusban ezt a 700-as MARC-személynévmezőben rögzítjük.

b) A másolat eredetijének keletkezési helye és ideje: az év általában szerepel a Dedek-katalógusban is. A rendszerint a másolat végén szereplő teljes

${ }^{17}$ Szentgyörgyi Rudolf: Korai oklevélgyűjteményeink nyelvtörténeti forrásértékéröl. = Helynévtörténeti tanulmányok. 2013. 9. sz. 77-88. p. 
keltezést kiolvassuk (szükség esetén feloldjuk a középkori dátumot), és ezt adjuk meg az egyik megjegyzés mezőben (599). Ha van helynév is, akkor a következőképpen: Helynév, év. hónap. nap., például: Buda, 1492. január 10. Bizonytalanság esetén feltüntetjük e mögött zárójelben a másolaton szereplő keltezést a szövegben álló formában. A rendszer sajátosságai miatt az itt leírt pontos dátumra csak akkor tudunk keresni az elektronikus katalógusban, ha pontok nélkül(!) fogalmazzuk meg a keresőkérdést, például: 1476 július 10

c) A másolat eredetijének keletkezési idejéhez kapcsolódóan feltüntetjük a jobb keresés, szükítési lehetőség biztosítása érdekében a szerepeltetett dátum évszázadát az egyik tárgyszó mezőben (653).

d) Megjegyzések: ha egyéb információt ki tudunk olvasni bizonyossággal a kéziratból, akkor azt rögzítjük egy másik megjegyzés mezőben: például ha van adat a másolás idejéről, vagy egyéb egyedi információ kerül elő. A fent megadott kiegészítő adatok segíthetik a kutatókat abban, hogy könnyebben megtalálják az őket érdeklő kéziratokat. Ezenkívül van még két fontos cél, amelyeknek a megvalósításához remélhetőleg valamelyest hozzájárul a digitalizált kéziratgyüjtemény és sajátos feldolgozása. Ezek a Borsa Iván által vázolt levéltáros feladatok, az egyik, hogy be kell azonosítani a másolatok közül azokat, amelyeknek nem maradt fenn az eredetije, a másik a másolók által használt források azonosítása. ${ }^{18} \mathrm{~A}$ fent vázolt katalogizálási mód támogathatja az első feladatot (a dátum és a kibocsátó alapján már utána lehet keresni az oklevélnek), a másodikat pedig a Dedek-katalógusból származó és a rekordokba felvett információ segítheti: ha meg volt jelölve a másolás helye, akkor az bejegyzésre került Dedek írását átvéve az egyik megjegyzés mezőbe.

A másolás helyének megjelölése rendkívül ritka, az ilyen adatot tartalmazó tételek az alábbi táblázatban láthatók:

\begin{tabular}{|l|l|l|l|l|}
\hline Gyüjtemény & Kötet & Tétel & \multicolumn{1}{|c|}{ Dedek szövegének részlete } & Forrás helye \\
\hline Hevenesi & 55 & 1 & $\begin{array}{l}\text { Ex MS. in archivio archiepisc. Viennen- } \\
\text { sis asservato }\end{array}$ & Bécsi érsekség \\
\hline Hevenesi & 55 & 5 & Copiae ex arch. ep. Vien. factae & Bécsi érsekség \\
\hline Hevenesi & 55 & 6 & Copiae ex arch. ep. Vien. comparatae & Bécsi érsekség \\
\hline Pray & 3 & 1 & $\begin{array}{l}\text { Copiae instrumentorum praepositurae } \\
\text { Veteris Budae, descriptae ex originali- } \\
\text { bus, depositis et existentibus in capitulo } \\
\text { Posoniensi }\end{array}$ & Pozsony \\
\hline
\end{tabular}

${ }^{18}$ Borsa i.m. 


\begin{tabular}{|c|c|c|c|}
\hline Kaprinai B & 10 & $\begin{array}{l}\text { Documenta ex archivo Barthphensi, Po- } \\
\text { soniensi, Lelesziensi et ab aliis commu- } \\
\text { nicata }\end{array}$ & $\begin{array}{l}\text { Pozsony, Lelesz, } \\
\text { Bártfa }\end{array}$ \\
\hline Kaprinai B & 13 & $\begin{array}{l}\text { Continet literas et documenta ad histo- } \\
\text { riam Mathiae Corvini illustrandam per- } \\
\text { tinentia. Ex archivo Bartphensi, Casso- } \\
\text { viensi, et camera Posoniensi }\end{array}$ & $\begin{array}{l}\text { Kassa, Pozsonyi } \\
\text { Kamara, Bártfa }\end{array}$ \\
\hline Kaprinai B & 16 & $\begin{array}{l}\text { Continet documenta ad historiam Hun- } \\
\text { gariae illustrandam pertinentia, ex ar- } \\
\text { chivo Nagybanyaensi et Felsőbanyaensi } \\
\text { scribit et conexscripta }\end{array}$ & $\begin{array}{l}\text { Nagybánya, Fel- } \\
\text { sőbánya }\end{array}$ \\
\hline Kaprinai B & 18 & $\begin{array}{l}\text { Continet diplomata, partim ex analec- } \\
\text { tis Thomae Szirmai, partim ex sty- } \\
\text { lo cancellariae Mathiae temporibus } \\
\text { coaevo, partim ex autographis a Sa- } \\
\text { muele Székely communicatis, et ex ar- } \\
\text { chivo civitatis Eperjes }\end{array}$ & Eperjes \\
\hline Kaprinai B & 19 & $\begin{array}{l}\text { Complectit documenta ex archivo civi- } \\
\text { tatis Szakolczensis }\end{array}$ & Szakolca \\
\hline Kaprinai B & 20 & $\begin{array}{l}\text { Continet diplomata ex archivo familiae } \\
\text { Sosianae, Chakianae, Vecseianae, et ab } \\
\text { aliis Viennae communicata. }\end{array}$ & Bécs \\
\hline Kaprinai B & 27 & $\begin{array}{l}\text { Continet documenta, ex archivo civita- } \\
\text { tis Cassoviensis deprompta }\end{array}$ & Kassa \\
\hline Kaprinai B & 29 & $\begin{array}{l}\text { Complectit diplomata ex archivo fami- } \\
\text { liae Sztáray; ex Cassoviens. civit. tabu- } \\
\text { lario; ex libro documentorum collegii } \\
\text { Cassoviens.; ad Preaposituram Mislen- } \\
\text { sem pertinentia }\end{array}$ & Kassa \\
\hline Kaprinai B & 38 & $\begin{array}{l}\text { Continet copias potissimum ex archivo } \\
\text { Bartfensi desumptas. }\end{array}$ & Bártfa \\
\hline Kaprinai B & 40 & $\begin{array}{l}\text { Continet copias ex tabulario Bartphensi, } \\
\text { et e Bohemia submissa, imo et ex monu- } \\
\text { mentis familiae Fiatth deprompta }\end{array}$ & $\begin{array}{l}\text { Csehország, Bárt- } \\
\text { fa }\end{array}$ \\
\hline Kaprinai B & 42 & $\begin{array}{l}\text { Complectit documenta ex tabulariis } \\
\text { civit. Bartfa et Eperjes exscripta. Item } \\
\text { privilegia Ruthenis Episcopis et sater- } \\
\text { dotibus concessa }\end{array}$ & Bártfa, Eperjes \\
\hline
\end{tabular}




\begin{tabular}{|l|l|l|l|l|}
\hline Kaprinai B & 57 & $\begin{array}{l}\text { Maxima e parte continet varia privilegia } \\
\text { ad episcopatum Nitriensem pertinentia }\end{array}$ & $\begin{array}{l}\text { Nyitrai püspök- } \\
\text { ség }\end{array}$ \\
\hline Kaprinai B & 62 & $\begin{array}{l}\text { Continet potissimum literas historiam } \\
\text { conventus Lelesziensis tempore praepo- } \\
\text { sitorum: Blasii, benedicti Korny, Eliae } \\
\text { et Joanni illustrantes }\end{array}$ & Lelesz \\
\hline
\end{tabular}

2. táblázat. A források és helynevek Dedek katalógusa alapján

Az ötödik oszlopban a helyre vonatkozó Dedek-részlet látszik, az utolsóban pedig a hely kiemelése. Összesen tizennyolc olyan esetet találtunk, ahonnan kiemelhető volt a forrás helye. Ezek a hozzáfüzések mind szerepelnek az adott kötetek rekordjainál úgy, mint a Dedek-kötetre vonatkozó megjegyzések. Annak eldöntése, hogy mely rekordokra érvényesek a megjegyzések, tehát hogy a kötet egészére vagy annak egy részére vonatkoznak, már a kutatás feladata. Ezekben a szövegekben találunk néha arra is utalást, hogy mely család levéltárából származnak a másolatok, ez is hasznos lehet a kutatók számára.

A forrás helye mellett néhány esetben a másoló, átnéző vagy másoltató neve is megtalálható, melyek szintén hozzájárulnak a kötetek keletkezési körülményeinek jobb megértéséhez. A Dedek-megjegyzésekből való kigyüjtés szerint az alábbi személyeket találjuk e funkcióban (a nevek mellett a gyüjteményrész, amelynél szerepelnek):

- Pethő István SJ - Pray 3,1.

- Péterffy Károly SJ - Kaprinai A 7-10., 15., 17-23.

- Cseles Márton SJ, Péterffy Károly SJ - Kaprinai A 12-14.

- Timon Sámuel, Péterffy Károly SJ - Kaprinai A 16.

- Szemere Pál - Kaprinai A 27., 30.

- Schmidt P. Miklós - Kaprinai A 34-36.

- Timon P. Sámuel SJ - Kaprinai A 37-45., 50.

- Székely Sámuel - Kaprinai B 18.

- Kaprinai István, Terstyánszky János - Kaprinai B 19.

- Wágner Károly SJ - Kaprinai B 23.

- Révay Antal - Kaprinai B 52.

A nevek az előfordulás sorrendjében szerepelnek. A személyek többsége jezsuita. Közülük kiemelhető Székely Sámuel, aki biztosan nem tartozott a jezsuita rendhez, viszont régiséggyüjtőként baráti viszonyt ápolt Kaprinai Istvánnal, akivel forrásanyagokat is cserélt, ezt bizonyítja a fennmaradt levelezésük. ${ }^{19} \mathrm{~A}$ másolókról Hóman is ír az idézett tanulmányában. ${ }^{20}$

${ }^{19}$ M. Horváth Mária (sajtó alá rend.): Dobai Székely Sámuel és Kaprinai István levelezése. Piliscsaba, PPKE BTK. 2008. 117 p.

${ }^{20}$ Hóman i.m. 
Befejezésképpen nézzük meg, hogy milyen eredményeket kapunk, ha csak egy bizonyos időintervallumból származó oklevelek érdekelnek minket! Ezt egy összetett kereséssel tudjuk lekérdezni századok szerint a könyvtár nyilvános katalógusában. A keresőkérdés egyik eleme a keresendő évszázad, például 15. sz. (feltétel: Tárgyi mezők), a másik pedig a kollekció kódja: Kaprinai B 2. kötete esetében collkaprb002* (feltétel: Gyüjt./ Jelzet). A következő diagram ábrázolja az ilyen jellegü keresést századok szerint. A 15. század 6 másolat esetében jelenik meg.

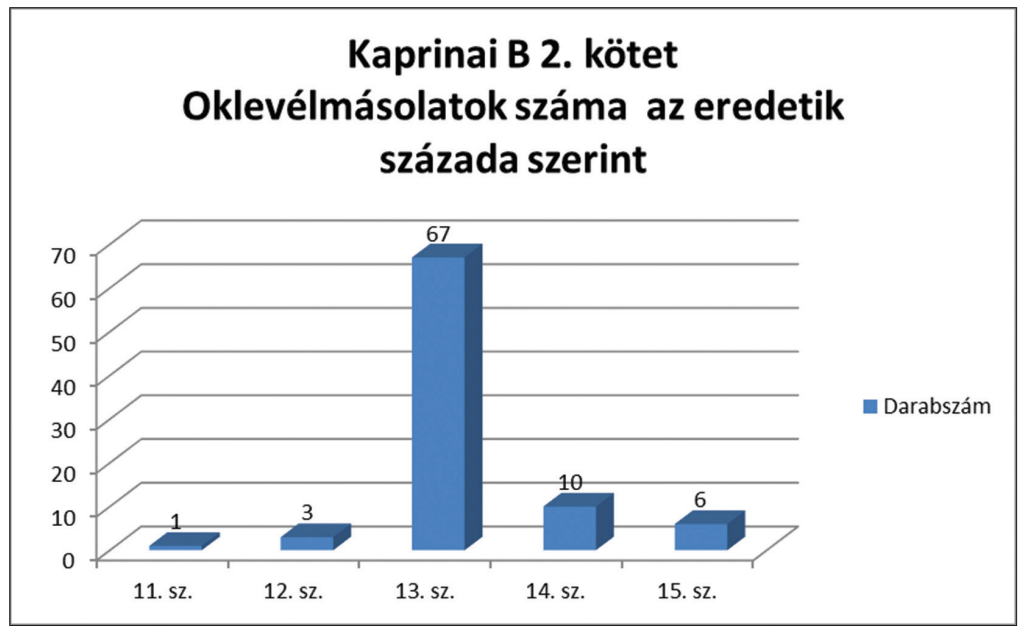

1. ábra. Századok szerint történő kimutatás - Kaprinai B 2. kötet

Ezt a lekeresést meg lehet tenni a jelenleg kiegészített, javított kötetnél (amenynyiben az oklevélmásolatokat tartalmaz), amelyek a mostani állás szerint a következők:

- Kaprinai B 2-3., 10-11., 13., 16., 19., 20., 37., 38., 44., 46., 61., 66., 70., 87.

- Pray 50.

A kötetek javítását és kiegészítését folyamatosan végezzük az integrált könyvtári rendszerben, mivel 12000 tételről van szó, ez hosszú távú feladat: az egy-egy történeti müvet tartalmazó kötet esetében gyorsabb, az oklevélmásolatokat, iratmásolatokat bíróknál időigényesebb (van amelyik kötetben több mint száz tétel található). Reményeink szerint ezzel közelebb hozzuk, kutathatóbbá tesszük az érdeklődők számára a kéziratos gyüjteményeket, és mind a Borsa Iván, mind a Tóth András által vázolt feladatok megvalósulását is elősegítjük, utóbbi azt foglalja magába, hogy szükséges lenne megállapítani, hogy mit publikáltak már a gyüjteményekből is mi az, amit még érdemes lenne közölni² ${ }^{21}$.

${ }^{21}$ Tóth András: Az Egyetemi Könyvtár kézirattárának fejlödése. = Egyetemi Könyvtár Évkönyve, 6. évf. 1972. p. 13-41. 


\section{Rezümé}

A tanulmány fó témái a Hevenesi-, Kaprinai-, Pray-kéziratgyüjtemények összetétele, valamint a könyvtári feldolgozásuk nehézségei és kihívásai. A kéziratok közül részletesebben foglalkozunk az 1526 előtti oklevélmásolatokkal, mivel a katalógusrekordok kiegészítését és javítási munkálatait ezzel a csoporttal kezdtük az Egyetemi Könyvtárban. Jelen írásban megismerkedünk továbbá a kollekcióban való keresés módjaival is és azzal, hogy a feldolgozás milyen speciális lekérdezési lehetőségeket kínál.

\section{The Problems of Cataloguing the Manuscript Collections of the Jesuit Scholars in the ELTE University Library}

The main topics of the paper are the structure of the Hevenesi, Kaprinai and Pray manuscript collections and the challenges of making their proper catalog records with a special regard to the diplomatic part of the collection (the collection of copies of medieval charters). We will describe also how to search easily in the collections and what kind of queries are offered to the users by this specific cataloging method.

MÁTYÁS MELINDA

informatikus könyvtáros

ELTE Eötvös Loránd Tudományegyetem Egyetemi Könyvtár ORCID: 0000-0003-0321-1658 